\title{
Conserving Soil Fertility and Sustaining Crop Performance Via Soil Tillage Systems and Crop Rotation
}

\author{
Lamy. M. M. Hamed ${ }^{1}$ Sara Fouda $^{2}$ and Eman I.R. Emara ${ }^{3}$
}

\begin{abstract}
Crop rotation / tillage impact on status of plant nutrients, crop production and soil properties was studied under North Sinai conditions, Egypt. The study assessed crop rotation (rice/clover (Berseem) / wheat/ soybean/ wheat (summers 2016 to 2018) under no tillage (NT) and conventional tillage (CT) systems and implications of crop and soil performance. CT revealed more positive implications over NT in few cases. Contents of available nutrients in soil after harvest were greater after legumes. Contents of $\mathrm{Fe}, \mathrm{Mn}$ and $\mathrm{Zn}$ in soil after crop harvest showed increases with CT than NT Rotation cropping maintained similar levels after legume crop especially compared to cereals crop. Crop productivity was in some cases higher CT than NT although NT increased plant chlorophyll, protein and proline.
\end{abstract}

Keywords: Legumes, No-Tillage, Cereal crops, Soil nutrients, Crop rotation

\section{INTRODUCTION}

Crop rotation and tillage system are major agricultural practices in sustainable farming. A proper crop rotation provides increased yields, nutrient uptake and soil available nutrients simultaneously with decreased pest and weed infection, as well as avoiding soil erosion. In some soils, no tillage may be beneficial with regard to conservation of soil structure (Machado et al., 2015) . Balanced crop rotation can improve soil structure and augment nutrient availability in soils besides attaining increased crop production (Shaalan et al., 2014; Dogan et al., 2008; Baumhardt and Anderson, 2006; Montemurro and Maiorana, 2008). Havlin et al. (1990) mentioned that adequate crop rotation involving alfalfa enriched soil with organic matter at considerable rates of up to $5 \mathrm{Mg} \mathrm{ha}^{-1}$. Combination of legumes and non-legumes and green manures can cause increased yields and improve soil fertility (Tosti et al., 2014 and Tribouillois et al., 2016). Riedill et al. (1998) applied a crop rotation involving cereals and legumes and noticed increased contents of total and available N. Legume residues can increase $\mathrm{N}$, soil fertility (Sharma and Behera 2008), improves soil pH (Hickman, 2002), and soil water / nutrient availability (Niu et al., 2017). Chan et al. (2008) reported that uptake of plant nutrients and soil structure depends on soil organic matter. Curtin et al. (2000) and Mc Conkey et al. (2012) reported that organic matter decomposition was promoted by conventional tillage more than no-tillage. Hickman (2002) reported that no tillage increased soil organic matter contents compared with conventional tillage, but conventional tillage increased available $\mathrm{K}$. Maillard et al. (2018) noted that tillage increased mineralization of nutrients. Irfan et al. (2013) reported that physical, chemical and biological properties of soil were all improved with no tillage Eck and Jones (1992) and Mitchell et al. (2017) applied no tillage over 15 years and obtained increases in soil aggregation, water infiltration, organic matter and nitrogen. Baumhardt et al. (2017) studied the effect of long term conventional tillage versus no tillage during over a rotation of wheatsorghum-fallow and grown on a clay loam soil and crop performance. They found that available soil water for $1.8 \mathrm{~m}$ profile averaged $194 \mathrm{~mm}$ for no tillage compared with $166 \mathrm{~mm}$ for conventional tillage. Vetsch and Randall (2004) reported leaf chlorophyll was highly correlated to maize grain yield. De Vita et al. (2007) obtained grater wheat grain yield and protein content under conventional tillage than no tillage. Crop residues were reported to be grater under no tillage than conventional tillage (Blanco-Canqui and Lai, 2009). Gentile et al. (2009) reported that the combine use of organic residues left by crops help in decreasing $\mathrm{N}$ loss from the soil/plant systems.

The main objective of the present work was to compare the no tillage and the conventional tillage applied over a rotation of rice (Orza sativa) / clover "Berseem" (Trifolium alexandrinum) / wheat (Triticum aestivum) / soybeans (Glycine max) / wheat grown on a loamy sand soil at El-Quntra Shark, Ismailia, Egypt.

\section{MATERIALS AND METHODS}

\section{Experiment location and site description:}

Field experiments were carried out in a farm at ElQuntra Shark, Ismailia $\left(30.85^{\circ} \mathrm{N} 32.31^{\circ} \mathrm{E}\right)$, Egypt, for two years from summer 2016 up to summer 2018 over rotations of rice (Orza sativa) / clover "Berseem" (Trifolium alexandrinum) / wheat (Triticum aestivum) / soybeans (Glycine max) / wheat on a sandy loam soil in

\footnotetext{
DOI: 10.21608/ASEJAIQJSAE.2019.31624

${ }^{1}$ Soil and Water Department, Faculty of Agriculture, Cairo University, Egypt

${ }^{2}$ Soil Sciences Department, Faculty of Agriculture, Zagazig University, Egypt

${ }^{3}$ Agronomy Department, Faculty of Agriculture, Cairo University, Egypt.

Received April 14, 2019, Accepted May 11, 2019
} 
at El-Quntra Shark, Ismailia, Egypt. Conventional tillage (CT) and no-tillage (NT) were applied. The main soil properties (Table 1) were determined according to methods cited in Klute (1986) and Page et al., (1982). Plant materials were analyzed for N P, K ,Fe, Mn and $\mathrm{Zn}$ contents using methods cited by Cottenie et al. (1982) while protein content was calculated by multiplying grain $\mathrm{N}$ content by 6.25 (FAO, 2003).

Usual agricultural practices were implemented except for the tillage. One set of rotation was subjected under conventional tillage (CT) while the other was under no tillage (NT). At the stare soil was ploughed then leveled using lazar technique. The filed drains were at a distance of $10 \mathrm{~m}$ between each other with a depth of $90 \mathrm{~cm}$. Fertilizer nutrients were applied at rates (as $\mathrm{kg}$ element per ha) as follows $\mathrm{N}: 240$ for rice , 180 for wheat, 48 for soybeans (as urea ; $640 \mathrm{~g} \mathrm{~N} \mathrm{~kg}^{-1}$ ), P $210 \mathrm{~kg} \mathrm{P} \mathrm{ha}^{-1}$ as ordinary superphosphate before rice planting (as ordinary superphosphate $68 \mathrm{~g} \mathrm{P} \mathrm{kg}^{-1}$ ) while $\mathrm{K}$ was at $150 \mathrm{~kg} \mathrm{~K} \mathrm{ha}^{-1}$ (in 2 equal splits doses " 21 and 45 days" after rice planting as K-Sulfate $400 \mathrm{~g} \mathrm{~K} \mathrm{~kg}^{-1}$ ).

Rice was planted on $25^{\text {th }}$ of April 2016, followed by clover (fahl) on the $10^{\text {th }}$ of September 2016 which stayed up to $25^{\text {th }}$ November 2016 , followed by wheat on the $30^{\text {th }}$ of November 2016 , followed by soybean on the $10^{\text {th }}$ May 2017 then followed by wheat on $30^{\text {th }}$ November 2017. In case of NT treatment, at end of season of each crop, plant residues of $15-\mathrm{cm}$ stems over soil surface were left on the soil and the following crop was sown without tillage. On the other hand, for CT treatment soil was tilled after harvest of each crop. Irrigation was done using water of El-Salam Canal (Agricultural drainage water mixed with Nile water at a $1: 1$ ratio). Table 2 shows the main properties of the water.

Table 1. The main physical and chemical properties of soil of the experiment site

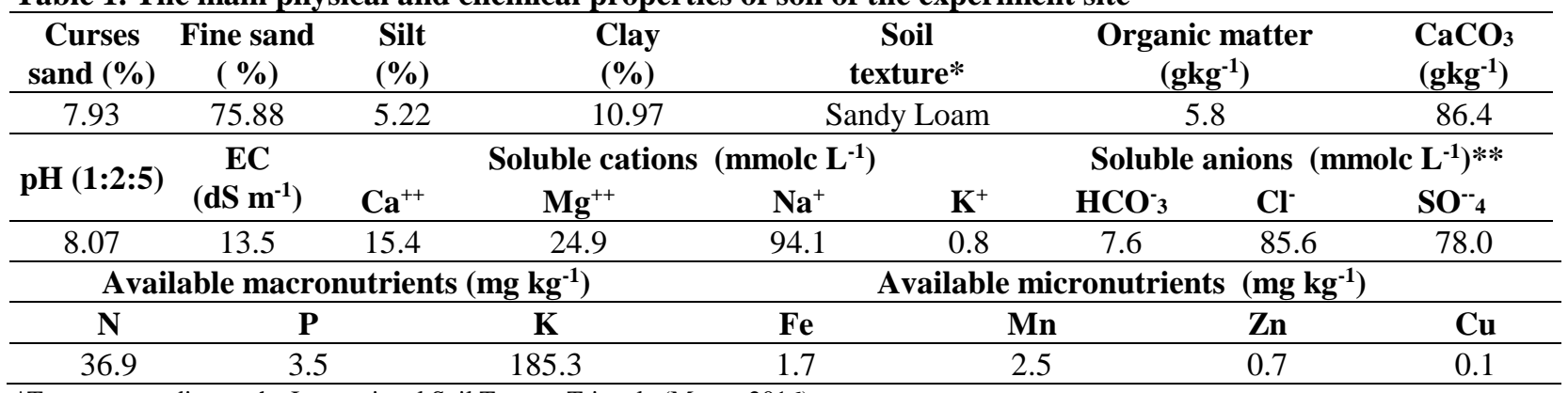

*Texture according to the International Soil Texture Triangle (Moeys 2016).

Table 2. Main properties of irrigation water (El-Salam Canal, Ismailia)

\begin{tabular}{|c|c|c|c|c|}
\hline Parameter & Season & April & September & November \\
\hline \multirow{2}{*}{ pH } & 2016 & 8.02 & 8.04 & 7.98 \\
\hline & 2018 & 8.00 & 8.03 & 7.99 \\
\hline \multirow{2}{*}{ EC } & 2016 & 1.25 & 1.55 & 1.36 \\
\hline & 2018 & 1.43 & 1.69 & 1.40 \\
\hline \multirow{2}{*}{$\mathrm{NO}^{-}{ }_{3-}-\mathrm{N}$} & 2016 & 18.62 & 20.47 & 17.62 \\
\hline & 2018 & 22.64 & 23.19 & 19.55 \\
\hline \multirow{2}{*}{$\mathrm{NH}^{-}{ }_{4-}^{-N}$} & 2016 & 9.14 & 10.98 & 9.72 \\
\hline & 2018 & 12.47 & 9.37 & 10.39 \\
\hline \multirow{2}{*}{$\mathbf{K}$} & 2016 & 10.95 & 8.14 & 7.93 \\
\hline & 2018 & 12.48 & 12.94 & 9.13 \\
\hline \multirow{2}{*}{$\mathbf{F e}$} & 2016 & 1.46 & 1.68 & 1.77 \\
\hline & 2018 & 1.50 & 1.88 & 1.85 \\
\hline \multirow{2}{*}{ Mn } & 2016 & 0.97 & 0.80 & 0.65 \\
\hline & 2018 & 0.83 & 0.98 & 0.73 \\
\hline \multirow{2}{*}{ Zn } & 2016 & 0.57 & 0.60 & 0.55 \\
\hline & 2018 & 0.66 & 0.67 & 0.58 \\
\hline
\end{tabular}




\section{Statistical analysis}

The experimental design was randomized complete block design with 3 replicates. The data collected were statistically analyzed using analysis of variance (ANOVA) according to the procedures outlined by Snedecor and Chochran (1967). To compare treatment means L.S.D at $5 \%$ level of significance was used according to Steel and Torrie (1980). All statistical analysis was performed by using MSTAT-C (1989) statistical software.

\section{RESULTS AND DISCUSSION}

\section{Yields}

The CT treatments showed slight, but not statistically significant, increase in productivity as well as in contents of chlorophyll, proline or protein (Table 3). Baumhardt et al. (2017) reported that NT may reduce evapotranspiration which affect plant leaf area and biomass that leads to greater yield potential, Alarcon et al. (2018) reported that tillage system caused no effect of legume yields. Al-Kaisi et al. (2016) mentioned that soybean yield were higher with CT system which they attributed to cold early spring under which conditions the NT system would cause slow seed germination and seedling emergence (Botta et al., 2010). There may be greater soil organic matter which would improve soil aggregation and high yield by NT (Franzluebbers, 2002; Yang et al., 2013; Yeboah et al., 2016).

Productivity in terms of grain yields for grain crops followed the pattern of rice> wheat > soy bean (Table 3). Pedersen and Lauer (2004) and Shahzad et al. (2016) reported that crop rotation has important implication for increase the crop productivity.

\section{Nutrients uptake by planrs}

Table 4 presented the nutrients uptake by different plants; legumes are of special interest in organic crop rotations. Therefore, legume crops in rotations improve $\mathrm{N}, \mathrm{P}$ and $\mathrm{K}$ uptake by crops, particularly in soybean and clover c. N'Dayegamiye et al. (2015) reported that legume crops in the rotation can provide a direct. There were increases in $\mathrm{N}, \mathrm{P}$ and $\mathrm{K}$ in wheat crop than in rice crop. Lower $\mathrm{Fe}, \mathrm{Mn}$ and $\mathrm{Zn}$ wheat, soybean and continuous wheat. Wei et al. (2006) which reported that uptake of $\mathrm{Fe}, \mathrm{Mn}$ and $\mathrm{Zn}$ were greater in clover and lowest with wheat.

\section{Soil pH, EC and available nutrients after harvest}

Table 5 shows Soil pH, Ec and available NPK, and Table 6 shows available micronutrients after harvest. Treatment of CT $\mathrm{pH}$ showed $\mathrm{pH}$ in the rice and clover soils being 7.91 to 7.92 respectively. However $\mathrm{pH}$ values were $8.21,8.11$, and 8.12 after wheat, soybean and wheat respectively. Available $\mathrm{N}$ increased to $46.35 \mathrm{mg} \mathrm{kg}^{-1}$ after tillage compared with 36.89 before cultivation. Long term cropping can degrade soil fertility (Wei et al., (2006). Legume crops residues contribute to organic $\mathrm{N}$ and after mineralization $\mathrm{N}$ increases in soil (Chu et al., 2004). Increased soil N occurred in NT as well as CT .Soil $\mathrm{P}$ values were increased compared with before cultivation. Among the nutrients deficiency of $\mathrm{P}$ in soil has an adverse impact of legume production as it is required enhanced N fixation (Rotaru and Sinclair 2009).

Table 3. Grain and straw yield, total chlorophyll, proline and protein content in in No-tillage (NT) and conventional tillage (CT) systems

\begin{tabular}{lcccccccccc}
\hline Field crop & $\begin{array}{c}\text { Grain Yield } \\
\text { (Ton/h) }\end{array}$ & \multicolumn{2}{c}{$\begin{array}{c}\text { Dry straw } \\
\text { (Ton/h) }\end{array}$} & \multicolumn{2}{c}{$\begin{array}{c}\text { Total } \\
\text { Chlorophyll } \\
(\mathbf{m g} / \mathbf{g})\end{array}$} & $\begin{array}{c}\text { Proline } \\
(\boldsymbol{\mu g} / \mathbf{g})\end{array}$ & \multicolumn{2}{c}{$\begin{array}{c}\text { Protein } \\
(\%)\end{array}$} \\
\cline { 2 - 11 } & $\mathrm{NT}$ & $\mathrm{CT}$ & $\mathrm{NT}$ & $\mathrm{CT}$ & $\mathrm{NT}$ & $\mathrm{CT}$ & $\mathrm{NT}$ & $\mathrm{CT}$ & $\mathrm{NT}$ & $\mathrm{CT}$ \\
\hline \multirow{2}{*}{ Rice } & 8.98 & 9.02 & 10.30 & 10.46 & 3.59 & 3.61 & 22.36 & 22.14 & 8.34 & 8.74 \\
& $\mathrm{Aa}$ & $\mathrm{Aa}$ & $\mathrm{Ba}$ & $\mathrm{Ba}$ & $\mathrm{Aa}$ & $\mathrm{Aa}$ & $\mathrm{BCa}$ & $\mathrm{Ba}$ & $\mathrm{Ca}$ & $\mathrm{Ca}$ \\
Clover & - & - & 16.44 & 17.59 & 4.25 & 4.33 & - & - & - & - \\
& & $\mathrm{Aa}$ & $\mathrm{Aa}$ & $\mathrm{Aa}$ & $\mathrm{Aa}$ & & & & \\
Wheat & 3.33 & 3.36 & 5.97 & 6.10 & 3.22 & 3.28 & 25.74 & 24.99 & 11.67 & 11.96 \\
& $\mathrm{Ba}$ & $\mathrm{Ba}$ & $\mathrm{BCa}$ & $\mathrm{BCa}$ & $\mathrm{Aa}$ & $\mathrm{Aa}$ & $\mathrm{ABa}$ & $\mathrm{ABa}$ & $\mathrm{BCa}$ & $\mathrm{BCa}$ \\
Soybean & 1.85 & 1.90 & 4.56 & 4.56 & 4.66 & 4.72 & 22.63 & 21.69 & 22.19 & 22.50 \\
& $\mathrm{Ba}$ & $\mathrm{Ba}$ & $\mathrm{Ca}$ & $\mathrm{Ca}$ & $\mathrm{Aa}$ & $\mathrm{Aa}$ & $\mathrm{BCa}$ & $\mathrm{BCa}$ & $\mathrm{Aa}$ & $\mathrm{Aa}$ \\
Wheat & 3.70 & 3.74 & 6.25 & 6.31 & 3.35 & 3.42 & 27.14 & 27.36 & 12.25 & 12.36 \\
& $\mathrm{Ba}$ & $\mathrm{Ba}$ & $\mathrm{BCa}$ & $\mathrm{BCa}$ & $\mathrm{Aa}$ & $\mathrm{Aa}$ & $\mathrm{Aa}$ & $\mathrm{Aa}$ & $\mathrm{Ba}$ & $\mathrm{Ba}$ \\
\hline
\end{tabular}

*Capital letters represented the significant different among different crop rotation and small letters represented the significant different among the tillage system. 
Table 4. Nutrients uptake in grains under different crop rotation treatments except clover in straw and notillage (NT) and conventional tillage (CT) systems

\begin{tabular}{|c|c|c|c|c|c|c|c|c|c|c|c|c|}
\hline \multirow{2}{*}{$\begin{array}{c}\text { Nutrients } \\
\text { Crop }\end{array}$} & \multicolumn{2}{|c|}{ N Uptake } & \multicolumn{2}{|c|}{ P Uptake } & \multicolumn{2}{|c|}{ K Uptake } & \multicolumn{2}{|c|}{ Fe Uptake } & \multicolumn{2}{|c|}{ Mn Uptake } & \multicolumn{2}{|c|}{ Zn Uptake } \\
\hline & NT & $\mathrm{CT}$ & NT & $\mathrm{CT}$ & NT & $\mathrm{CT}$ & NT & $\mathrm{CT}$ & NT & $\mathrm{CT}$ & NT & $\mathrm{CT}$ \\
\hline \multirow{2}{*}{ Rice } & 83.23 & 87.25 & 13.77 & 16.65 & 133.7 & 138.3 & 5471.4 & 5582.7 & 3462.9 & 3609.9 & 2244.3 & 2353.4 \\
\hline & $\mathrm{Aa}$ & Aa & $\mathrm{Aa}$ & $\mathrm{Ca}$ & $\mathrm{Aa}$ & $\mathrm{Aa}$ & $\mathrm{Ca}$ & $\mathrm{Ba}$ & $\mathrm{Ba}$ & $\mathrm{Ba}$ & $\mathrm{Aa}$ & $\mathrm{Aa}$ \\
\hline \multirow{2}{*}{ Clover } & 183.1 & 186.6 & 25.83 & 33.29 & 138.5 & 159.0 & 3329.2 & 3491.6 & 2635.8 & 2805.7 & 1572.8 & 1613.5 \\
\hline & Aa & Aa & $\mathrm{Aa}$ & Aa & Aa & Aa & Ea & $\mathrm{Ca}$ & $\mathrm{Ca}$ & $\mathrm{Ca}$ & $\mathrm{Ca}$ & $\mathrm{Ca}$ \\
\hline \multirow{2}{*}{ Wheat } & 116.5 & 119.4 & 18.37 & 18.37 & 140.1 & 141.2 & 6319.7 & 6473.6 & 4496.7 & 4540.3 & 1836.2 & 1925.8 \\
\hline & Aa & $\mathrm{Aa}$ & Aa & $\mathrm{Ca}$ & Aa & Aa & $\mathrm{Ba}$ & Aa & Aa & Aa & $\mathrm{Bb}$ & $\mathrm{Ba}$ \\
\hline \multirow{2}{*}{ Soybean } & 203.8 & 206.6 & 25.83 & 25.83 & 159.6 & 160.7 & 6460.4 & 6652.7 & 4355.5 & 4541.5 & 2108.9 & 2181.2 \\
\hline & Aa & Aa & Aa & $\mathrm{Ba}$ & Aa & Aa & Aa & Aa & Aa & Aa & Aa & Aa \\
\hline \multirow{2}{*}{ Wheat } & 122.3 & 123.4 & 18.94 & 21.24 & 146.9 & 149.2 & 5113.8 & 5197.6 & 4604.6 & 4618.9 & 1600.3 & 1691.6 \\
\hline & Aa & Aa & Aa & $\mathrm{BCa}$ & Aa & Aa & Da & $\mathrm{Ba}$ & $\mathrm{Aa}$ & Aa & $\mathrm{Ca}$ & $\mathrm{Ca}$ \\
\hline
\end{tabular}

Table 5. pH, EC and macronutrients content in the experimental site after harvest in No-tillage (NT) and conventional tillage (CT) systems

\begin{tabular}{|c|c|c|c|c|c|c|c|c|c|c|}
\hline \multirow{3}{*}{ Field crop } & \multirow{2}{*}{\multicolumn{2}{|c|}{ pH (1:2.5) }} & \multirow{2}{*}{\multicolumn{2}{|c|}{$\mathrm{EC}\left(\mathrm{dSm}^{-1)}\right.$}} & \multicolumn{6}{|c|}{ Macronutrients ( $\left.\mathrm{mg} \mathrm{kg}^{-1}\right)$} \\
\hline & & & & & \multicolumn{2}{|c|}{$\mathbf{N}$} & \multicolumn{2}{|c|}{$\mathbf{P}$} & \multicolumn{2}{|c|}{$\mathbf{K}$} \\
\hline & NT & CT & NT & CT & NT & $\mathrm{CT}$ & NT & CT & NT & $\mathrm{CT}$ \\
\hline \multirow{2}{*}{ Rice } & \multirow{2}{*}{7.91} & \multirow{2}{*}{8.01} & \multirow{2}{*}{11.10} & \multirow{2}{*}{8.21} & 38.02 & 41.25 & 3.57 & 3.72 & 188.3 & 192.4 \\
\hline & & & & & $\mathrm{Eb}$ & $\mathrm{Aa}$ & $\mathrm{Aa}$ & $\mathrm{Aa}$ & $\mathrm{Ca}$ & $\mathrm{Ca}$ \\
\hline \multirow{2}{*}{ Clover } & \multirow{2}{*}{7.92} & \multirow{2}{*}{7.82} & \multirow{2}{*}{7.00} & \multirow{2}{*}{7.09} & 42.77 & 44.29 & 3.98 & 4.50 & 203.6 & 207.1 \\
\hline & & & & & $\mathrm{Ba}$ & $\mathrm{Aa}$ & $\mathrm{Aa}$ & $\mathrm{Aa}$ & $\mathrm{Ba}$ & $\mathrm{Ba}$ \\
\hline \multirow{2}{*}{ Wheat } & \multirow{2}{*}{8.21} & \multirow{2}{*}{8.16} & \multirow{2}{*}{8.10} & \multirow{2}{*}{6.38} & 42.32 & 42.98 & 3.94 & 4.88 & 201.4 & 205.2 \\
\hline & & & & & $\mathrm{Ca}$ & $\mathrm{Aa}$ & $\mathrm{Aa}$ & $\mathrm{Aa}$ & $\mathrm{Ba}$ & $\mathrm{Ba}$ \\
\hline \multirow{2}{*}{ Soybean } & \multirow{2}{*}{8.11} & \multirow{2}{*}{8.12} & \multirow{2}{*}{7.00} & \multirow{2}{*}{6.75} & 44.33 & 44.07 & 4.06 & 4.15 & 209.6 & 214.1 \\
\hline & & & & & $\mathrm{Aa}$ & Aa & $\mathrm{Aa}$ & $\mathrm{Aa}$ & $\mathrm{Ab}$ & $\mathrm{Aa}$ \\
\hline \multirow{2}{*}{ Wheat } & \multirow{2}{*}{8.13} & \multirow{2}{*}{8.11} & \multirow{2}{*}{7.30} & \multirow{2}{*}{6.85} & 41.37 & 46.35 & 3.91 & 4.46 & 205.6 & 207.0 \\
\hline & & & & & $\mathrm{Da}$ & $\mathrm{Aa}$ & $\mathrm{Aa}$ & $\mathrm{Aa}$ & $\mathrm{ABa}$ & $\mathrm{Ba}$ \\
\hline
\end{tabular}

*Capital letters represented the significant different among different crop rotation and small letters represented the significant different among the tillage system.

Table 6. Micronutrients content in the experimental site after harvest in No-tillage (NT) and tillage (T) systems

\begin{tabular}{|c|c|c|c|c|c|c|}
\hline \multirow{3}{*}{ Field crop } & \multicolumn{6}{|c|}{ Micronutrients $\left(\mathrm{mg} \mathrm{kg}^{-1}\right)$} \\
\hline & \multicolumn{2}{|c|}{$\mathbf{F e}$} & \multicolumn{2}{|c|}{ Mn } & \multicolumn{2}{|c|}{$\mathbf{Z n}$} \\
\hline & NT & $\mathbf{T}$ & NT & $\mathbf{T}$ & NT & $\mathbf{T}$ \\
\hline Rice & $1.71 \mathrm{Ba}$ & $1.79 \mathrm{Ca}$ & $2.62 \mathrm{Ba}$ & $2.65 \mathrm{Ba}$ & $0.71 \mathrm{Ba}$ & $0.72 \mathrm{Ba}$ \\
\hline Clover & $1.85 \mathrm{Aa}$ & $1.99 \mathrm{Aa}$ & $2.77 \mathrm{Aa}$ & $2.81 \mathrm{Aa}$ & $0.75 \mathrm{ABa}$ & $0.86 \mathrm{Aa}$ \\
\hline Wheat & $1.90 \mathrm{Aa}$ & $1.91 \mathrm{Ba}$ & $2.71 \mathrm{ABa}$ & $2.78 \mathrm{Aa}$ & $0.74 \mathrm{ABa}$ & $0.83 \mathrm{Aa}$ \\
\hline Soybean & $1.86 \mathrm{Aa}$ & $1.98 \mathrm{Aa}$ & $2.77 \mathrm{Aa}$ & $2.76 \mathrm{Aa}$ & $0.78 \mathrm{ABa}$ & $0.86 \mathrm{Aa}$ \\
\hline Wheat & $1.84 \mathrm{Aa}$ & $1.86 \mathrm{Ba}$ & $2.70 \mathrm{ABa}$ & $2.76 \mathrm{Aa}$ & $0.83 \mathrm{Aa}$ & $0.83 \mathrm{Aa}$ \\
\hline
\end{tabular}

*Capital letters represented the significant different among different crop rotation and small letters represented the significant different among the tillage system.

Deficiency of $\mathrm{P}$ in soil directly affects roots growth, photosynthesis, sugar translocation which in turn directly or indirectly disturbs $\mathrm{N}$-fixation (Martin-Rueda et al., 2007). Soil K was increased particularly after soybeans. Soon and Arshad (1996) reported the K was decreased by cropping systems. Long term studies by Jonston (1969) Hickman (2002) noted little change in K after more than 100 years of cultivation of no $\mathrm{K}$ fertilization.

Contents of $\mathrm{Fe}, \mathrm{Mn}$ and $\mathrm{Zn}$ in soil after crop harvest shows increases in the CT than the NT systems. Rotation cropping maintained similar levels after legume crop especially compared to cereals crop. Hickman, (2002) found that reduced tillage resulted 
increased Fe, Mn and Zn. While, Martin-Rueda etal. (2007) found that minimum tillage leads to higher Fe, $\mathrm{Mn}$ and $\mathrm{Zn}$ in the upper layer soil.

\section{CONCLUSION}

Crop rotation is a critical feature of all sustainable cropping systems because it provides the principal mechanism for building healthy soils, a major way to control pests along with a variety of other benefits. Crops productivity was rather higher under conventional tillage system compared with the NT system. Legumes increased $\mathrm{N}, \mathrm{P}$ and $\mathrm{K}$ availability by crop. Higher Fe, $\mathrm{Mn}$ and $\mathrm{Zn}$ were obtained by clover wheat soybeans than rice.

\section{REFERENCES}

Alarcon, R., E. Hernandez-Plaza, L. Navarrete, M.J. Sanchez, A. Escudero, J.L.Herananz, V.Sanchez-Giron and A.M. Sanchez. 2018. Effects of no-tillage and non-inversion tillage on weed community diversity and crop yield over nine years in Mediterranean cereal-legume cropland. Soil and Till. Res. 179: 54-62. http://doi.org/10.1016/j.still.2018.01.014

Al-Kaisi, M.M., S. Archontoulis, and D. Kwaw-Mensah. 2016. Soybean spatiotemporal yield and economic variability as affected by tillage and crop rotation. Agron. $\begin{array}{llll}\text { J., } & 108 & \text { (3): }\end{array}$ http://doi.org/10.2134/agronj2015.03633

Baumhardt, R.L. and R.L. Anderson. 2006. Crop choices and rotation principles. In: G.A. Peterson et al., editors, Dryland agriculture. $2^{\text {nd }}$ ed. Agron. Monogr. 23. ASA, CSSA and SSSA, Madison, WI. P:113-139.

Baumhardt, R.L., R.C. Schwartz, O.R.Jones, B.R. Scanlon, R.C. Reedy and G.W. Marek.2017. Long-term conventional and no-tillage effects on field hydrology and yields of a dryland crop rotation. Soil Sci. Soc. Am. J. 81:200-209. doi:10.2136/sssaj2016.08.0255

Blanco-Canqui, H. and R. Lai. 2009. Crop residue removal impacts on soil productivity and environmental quality. Critical Reviews in Plant Sciences. 28: 139 163. https://doi.org/10.1080/07352680902776507

Botta, G.F., A. Tolon-Becerra, X. Lastra-Bravo and M. Tourn. 2010. Tillage and traffic effect (planters and tractors) on soil compaction and soybean (Glycine max L.) yields in Argentina pampas. Soil and Till. Res. 110: 167-174. http://doi.org/10.1016/j.still.2010.07.001

Chan, K.Y., A. Cowie, G. Kelly, B. Singh and P. Slavich. 2008. Scoping Paper: Soil Organic Carbon Sequestration Potential for Agriculture in NSW. NSW Department of Primary Industries, Science Res. Tech. paper. Pp:1-29. https://www.dpi.nsw.gov.au/content/research/areas/soilsrecycled-organics/scientific-outputs/2008/soil_organic

Chu, C., J.L. Spencer, M.J. Curzi, J.A. Zavala, and M.J. Seufferheld. 2004. Gut bacteria facilitate adaptation to crop rotation in the western corn rootworm. Proc. Natl. Acad. Sci. USA 110:11917-11922. https://doi.org/10.1073/pnas.1301886110
Cottenie, A., M. Verloo, L. Kickens, G. Velghe and R. Camerynch. 1982. Chemical Analysis of Plants and Soils. Laboratory of analytical and Agrochemistry, State Univ., Ghent, https://lib.ugent.be/catalog/rug01:001462434

Belgium.

Curtin, D., H. Wang, F. Selles, B.G. McConkey and C.A. Campbell. 2000. Tillage effects on carbon fluxes in continuous wheat and fallow-wheat rotations. Soil Sci. Soc. Am. J. 64:2080-2086. doi:10.2136/sssaj2000.6462080x

De Vita, P., E. Di Paolo, G. Fecondo, N. Di Fonzo, and M. Pisante. 2007. No tillage and conventional tillage effects on durum wheat yield, grain quality and soil moisture content in southern Italy. Soil and Till. Res. 92: 69-78. http://doi.org/10.1016/j.still.2006.01.0122

Dogan, E., T. A.Goksoy, K. Yagdi, and M. Z. turan. 2008. Comparison of the effects of different crop rotation systems on winter wheat and sunflower under rain-fed conditions. African J. of Bioltechnology 7 (22): 40764082.

https://www.ajol.info/index.php/ajb/article/view/59518

Eck, H.V., and O.R. Jones. 1992. Soil nitrogen status as affected by tillage, crops, and crop sequences. Agron. J. 84:660-668.

DOI: $10.2134 /$ agronj1992.00021962008400040025x

FAO. 2003. Food energy - methods of analysis and conversion factors. FAO Food and Nutrition Paper 77.FAO, Rome.

Franzluebbers, A.J. 2002. Soil organic matter stratification ratio as an indicators of soil quality. Soil and Till. Res. 66: 95-106. https://doi.org/10.1016/S0167-1987(02)00018-1

Gentile, R., B.Vanlauwe, C. Van Kessel and J. Six. 2009. Managing $\mathrm{N}$ availability and losses by combining fertilizer-N with different quality residues in Kenya. Agri. Ecosystems and Environ. 131:308314. https://doi.org/10.1016/j.agee.2009.02.003

Havlin, J.L., D.E. Kissel, L.D. Maddux, M.M. Claassen, and J.H. Long. 1990. Crop rotation and tillage effects on soil organic carbon and nitrogen Soil Sci. Soc. Am. J. 54:448452. doi:10.2136/sssaj1990.03615995005400020026x

Hickman, M. V. 2002.long-term tillage and crop rotation effects on soil chemical and mineral properties. Journal of plant nutrition. 25(7): 1457-1470. Published online (2007) https://doi.org/10.1081/PLN-120005402

Irfan, A., M. Tariq and I. Rafiq. 2013. Effect of long term notill and conventional tillage practices on soil quality. J. Soil and Till. Res. 131 (7): 28-35. https://doi.org/10.1016/j.still.2013.03.002

Jonstone, D.R., Formulations and atomization, Proc. 4 th., inl. Agric. Avait. Cogr .1969.Kingston, Ontario:225-233.

Julien Moeys. 2016. soiltexture: Functions for Soil Texture Plot, Classification and Transformation. $\mathrm{R}$ package version 1.4.1. $\quad$ https://CRAN.Rproject.org/package $=$ soiltexture 
Klute, A. 1986. Methods of Soil Analysis (second ed.) American Society of Agronomy, Inc. Soil Science Society of America. Madison, Wisconsin. USA.

Machado, S., L. Pritchett and S. Petrie. 2015. No-tillage cropping systems can replace traditional summer fallow in North-Central Oregon. Agron. J. 107. doi:10.2134/agronj14.0511

Maillard, E., B.G. McConkey, M.S. Luce, D.A. Angers, and J. Fan. 2018. Crop rotation, tillage system, and precipitation regime effects on soil carbon stocks over 1 to 30 years in Saskatchewan, Canada. Soil and Till. Res., 177: 97-104. https://doi.org/10.1016/j.still.2017.12.001

Martin-Rueda I., L.M.F. Muñoz-Guerraa, E. Yuntaa, J.L.Estebana, J.J. Tenoriob, and Lucenaa. 2007. Tillage and crop rotation effects on barley yield and soil nutrients on a Calciortidic Haploxeralf. Soil Till.Res.92.1-2:1-9. https://doi.org/10.1016/j.still.2005.10.006

Mc Conkey, B.G., C.A. Campbell, R.P. Zentner, M. Peru and A.J.VandenBygaart. 2012. Effect of tillage and cropping frequency on sustainable agriculture in the Brown Soil zone. Prairie Soils Crops J. 5:51-58. http://www.prairiesoilsandcrops.ca

Mitchell, J.P., A. Shrestha, K. Mathesius, K.M.Scow, R.J. Southard, R.L.Haney, R.Schmidt, D.S. Munk and W.R. Horwath. 2017. Cover cropping and no-tillage improve soil health in an arid irrigated cropping system in California's San Joaquin Valley, USA. Soil and Till. Res., 165: 325-335. http://dx.doi.org/10.1016/j.still.2016.09.001

Montemurro F. and M. Maiorana. 2008. Organic Fertilization as Resource for a Sustainable Agriculture, Fertilizers: Properties, Applications and Effects, in: Elsworth L.R. et al. (Eds.), pp. 123-146, ISBN 978- 1-60456-483-9.

Mstat-C. 1989. Users Guide: A microcomputer program for the design, management and analysis of agronomic research experiments. Michigan Univ., East Lausing, MC, USA.

N'Dayegamiye, A. J., J.K. Nyiraneza, M. Whalen, Grenier and A. Drapeau.2012. Growing soybean prior to corn increased soil nitrogen supply and

$\mathrm{N}$ fertilizer efficiency for corn in cold and humid conditions of EasternCanada. Sust. Agric. Res. 1:257-267 DOI: $10.5539 /$ sar.v1n2p257

Niu, Y., L.D.Bainard, M. Bandara, C. Hamel and Y. Gan. 2017. Soil residual water and nutrients explain about $30 \%$ of the rotational effect in 4-yr pulse-intensified rotation systems. Can. J. Plant Sci. 97: 852-864. https://doi.org/10.1139/cjps-2016-0282

Page, A.L., R.H. Miller and D.R. Keeney. 1982. "Methods of Chemical Analysis". Part 2: Chemical and microbiological properties (Second Edition). American Society of Agronomy, Inc. and Sci. Soc. of America, Inc. Publishers, Madison, Wisconsin U.S.A.

Pedersen, P. and J.G. Lauer. 2004. Soybean growth and development response to rotation sequence and tillage system. Agron. J. 96: 1005- 1012. http://doi.org/agronj2004.1005
Riedill, W.E., T.E. Schumacher, S.A. Clay, M.M.Ellsbury, M. Pravecek, P.D. Evenson. 1998. Corn and Soil Fertility Responses to Crop Rotation with Low, Medium, or High Inputs. Crop Sci., 38: 427-433. doi:10.2135/cropsci1998.0011183X003800020026x

Rotaru, V. and T. R. Sinclair. 2009. Influence of plant phosphorus and iron concentrations on growth of soybean. Journal of Plant Nutrition 32(9):1513-1526. DOI: $10.1080 / 01904160903093828$

Shaalan, A.M., N.R. Ahmed, A.S.A. Shams and H.E. Khalil. 2014. Rotational crop sequences and N fertilization levels effect on maize growth and productivity. Alex. Sci . Exch. J. 35: 154 - 161 .

Shahzad, M., M. Farooq, K. Jabran and M. Hussain. 2016 Impact of different crop rotations and tillage systems on weed infestation and productivity of bread wheat. Crop Protection, 89: 161-169. http://dx.doi.org/10/1016/j.cropro.2016.07.019

Sharma, A.R., and U.K. Behera. 2008. Recycling of legume residues for nitrogen economy and higher productivity in maize (Zea mays) — wheat (Triticum aestivum) cropping system. Nutr. Cycling Agroecosyst. 83: 197-210. https://doi.org/10.1007/s10705-008-9212-0

Snedecor, G.V. and W.G. Cochran. 1967. Statistical methods. 6th Ed Iowa State Univ. Press, Ames, Iowa, USA.

Soon, Y.K. and M.A. Arshad. 1996. Effects of cropping systems on nitrogen, phosphorus and potassium forms and soil organic carbon in a Gray Luvisol. Biol. Fertil. Soils 22:184-190. https://doi.org/10.1007/BF00384453

Steel, R.G. and H.H. Torrie. 1980. Principles and procedures of statistics. second Ed. McGraw Hill. New York. https://trove.nla.gov.au/work/9171434

Tosti, G., P. Benincasa, M. Farneselli, F. Tei and M. Guiducci. 2014. Barley-hairy vetch mixture as cover crop for green manuring and the mitigation of $\mathrm{N}$ leaching risk. $\begin{array}{lll}\text { Eur. J. } & \text { Agron. }\end{array}$ https://doi.org/10.1016/j.eja.2013.11.012

Tribouillois, H., J.-P. Cohan, and E. Justes. 2016. Cover crop mixtures including legume produce ecosystem services of nitrate capture and green manuring: assessment combining experimentation and modelling. Plant Soil 401: 347-364. https://doi.org/10.1007/s11104-015-2734-8

Vetsch, J.A. and G.W. Randall. 2004. Corn production as affected by nitrogen application timing and tillage. Agron. J. 96:502-509. http://doi.org/10.2134/agronj2004.5020

Wei X., M. Hao, M. Shao and W.J. Gale. 2006. Change in soil properties and availability of soil micronutrients after 18 years of cropping and fertilization. Soil Till.Res. 91:120130. https://doi.org/10.1016/j.still.2005.11.009

Yang, X.M., C.F. Drury and M.M. Wander. 2013. A wide view of no-tillage practices and organic carbon sequestratation. Acta Agriculturae Schandinavica, Section B-Soil and Plant Sci. 63: 523-530. https://doi.org/10.1080/09064710.2013.816363 
Yeboah, S., R. Zhang, L. Cai, L. Li, J. Xie, Z. Luo, J. Liu and J. Wu . 2016. Tillage effect on soil organic carbon, microbial biomass carbon and crop yield in spring wheat-

\section{الملخص العربي}

المحافظة علي خصوبة التربة وكفاعة المحاصيل من خلال إدارة نظم حرث التربة وإستخدام الاورات الزراعية

لامي ممدوح محمد حامد، سارة فودة، إيمان إبر اهيم رفاعي عمارة

البقولية. هذا بلإضافة إلي زيادة في محتوى كلا من الحديد

و والمنجنيز (Me) في التربة بعد حصاد المحصول (Fe)

البقولي تحت نظم الحر اثة التقليدية (CT) عنه تحت نظم عد

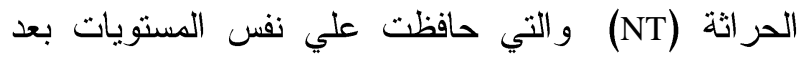

حصاد المحاصيل البقولية مقارنة بمحاصيل الحبوب.

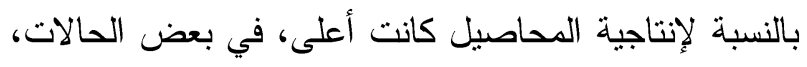

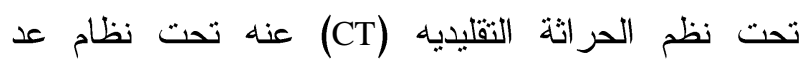

الحر اثة (NT)، بالرغم من زيادة محتوى الكلوروفيل في

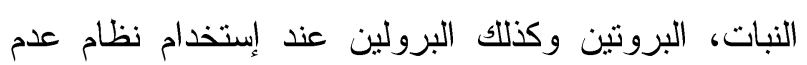

$$
\text { الحراث (NT) (النات، البروتين }
$$

الكلمات الالة: البقوليات، اللاحر اثة، محاصيل الحبوب،

$$
\text { مغذيات التربة، الدورة الزر اعية. }
$$

field pea rotation. Plant Soil Environ. 62 (6): 279-285. http://doi.org/10.17221/66/2016
تأثير الدورات الزراعية / نظم الحراثة علي حالة

التغذية في النبات، و إنتاجية المحاصيل وخصائص التربة كان هو الهدف الرئيسي من إجراء الدراسة التي تمت شمال واله

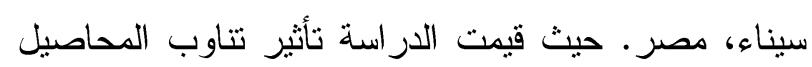

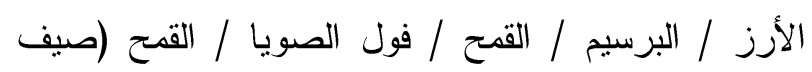

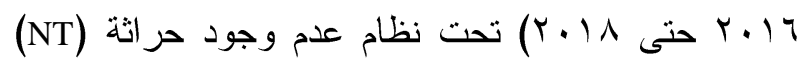
ونظام الحراثة التقليدية (CT)، علي أداء وكفاءة المحاصيل وكذللك خصائص التربة.

أظهرت النتائج بعض السمات الإيجابة لنظام الحراثة

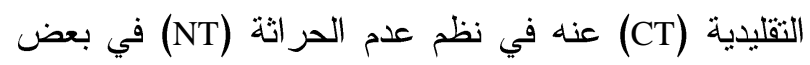
الحالات تحت التجربة المقامة. حيث كان محتوى المغذيات النباتية في التربة بعد الحصاد أكبر بعد حصاد المحاصيل 